\title{
LIPOPOLYSACCHARIDE OF PSEUDOMONAS MANDELII, ISOLATED FROM ANTARCTICA
}

\author{
O.S. Brovarska, L.D. Varbanets, G.V. Gladka, \\ A.D. German, O.B. Tashyrev \\ Zabolotny Institute of Microbiology and Virology, NAS of Ukraine, \\ 154 Acad. Zabolotny Str., Kyiv, 03143, Ukraine \\ e-mail:varbanets_imv@ukr.net
}

Representatives of the Pseudomonas mandelii species are able to exist and multiply in places where the temperature is constantly low. The optimum growth temperature for P. mandelii is 25$30^{\circ} \mathrm{C}$, although this bacterium can grow at $4{ }^{\circ} \mathrm{C}$ but not at $37^{\circ} \mathrm{C}$. Therefore, P. mandelii is an excellent example of psychrotolerant bacterium which like psychrophilic bacteria is characterized by a number of structural and functional adaptations that facilitate survival at low temperatures. To understand these microorganisms'role in Antarctica the characterization of its biopolymers is vital. One of these biopolymers is lipopolysaccharide (LPS), composition and structure of which are diagnostically significant. This determines the aim of the work - to isolate lipopolysaccharides from the cells of Antarctic strain of P. mandelii, grown at different temperatures, to characterize them chemically, and to study their functional and biological activity. Methods. The object of the study was Pseudomonas sp. U1, isolated from moss on Galindez Island in Antarctica. Lipopolysaccharides were extracted from dried cells by $45 \%$ phenol water solution at $65-68{ }^{\circ} \mathrm{C}$ by Westphal and Jann method. The amount of carbohydrates was determined by phenol-sulfuric method. Carbohydrate content was determined in accordance to the calibration curve, which was built using glucose as a standard. The content of nucleic acids was determined by Spirin, protein - by Lowry method. Serological activity of LPS was investigated by double immunodiffusion in agar using the method of Ouchterlony. Polyacrylamide gel electrophoresis in the presence of sodium dodecyl sulfate (SDS-PAAG electrophoresis) was performed according to Laemmli. Results. As a result of phylogenetic analysis (programs ClustalX 2.1, Tree view, Mega v. 6.00) it was shown that the Antarctic bacterial strain Pseudomonas sp. U1 associated with green moss has a $99.4 \%$ homology with the type strain from the GenBank database NR024902 P. mandelii CIP 105273T. According to these data and proximity to the corresponding cluster of species, the studied isolate can be identified as $P$. mandelii. A characteristic feature of LPS isolated from P. mandelii cells, grown at different temperatures $\left(20^{\circ} \mathrm{C}\right.$ and $\left.4{ }^{\circ} \mathrm{C}\right)$ is their heterogeneity. This is evidenced by the data of the monosaccharide composition, electrophoretic distribution, which showed that P. mandelii produces S- and SR-forms of LPS, differed in the length of the O-specific polysaccharide chains. The R-form of LPS is also present, which does not contain an O-specific polysaccharide chains. Structural heterogeneity is also inherent in LPS lipid A. This is evidenced by the data of the fatty acid composition. In LPS grown at $4{ }^{\circ} \mathrm{C}$ no unsaturated fatty acids were found, while such ones are synthesized in LPS of other bacteria grown in the cold, in response to a decrease in growth temperature. The study of the immunochemical properties of LPS was carried out using polyclonal O-antisera as antibodies, and LPS as antigens indicated that in homologous systems LPS exhibited serological activity. LPS obtained from P. mandelii U1 cells, grown at $20^{\circ} \mathrm{C}$, had a complex antigenic composition and gave two clear lines of precipitation at a concentration of $1 \mathrm{mg} / \mathrm{mL}$. LPS obtained from P. mandelii U1 cells, grown at $4{ }^{\circ} \mathrm{C}$, gave one line, which indicates their serological homogeneity. Conclusions. For the first time lipopolysaccharides were isolated from cells of P. mandelii U1, grown at $4{ }^{\circ} \mathrm{C}$ and $20^{\circ} \mathrm{C}$. A characteristic feature of these LPS is their heterogeneity. This is evidenced by the data of the monosaccharide and fatty acid composition, electrophoretic distribution, which showed that P. mandelii produces $S$ - and SR-forms of LPS, differed in the length of the O-specific polysaccharide chains. LPS, obtained from cells, grown at different temperatures, are differed by serological activity.

Keywords: Antarctic strain Pseudomonas mandelii U1, lipopolysaccharide, monosaccharide and fatty acid composition, pyrogenicity, serological activity. 
Antarctica is arguably one of the planet's harshest environments: intense cold, low humidity, a limited availability of liquid water, as well as periods of high solar radiation and extended total darkness mean that the continent represents a relatively inhospitable environment for the development of the life. Despite these extreme conditions, microorganisms such as bacteria, archae, fungi and microalgae are the dominant lifeforms in the Antarctic ecosystems. A bacterial genus that has appeared frequently in Antarctic research is Pseudomonas. The first Pseudomonas found in the Antarctic was described by Kriss et al. [1], and since this time, a number of new species have been reported. While efforts towards new species discovery accelerated after the year 2000, until recently only eight Pseudomonas species have been described in Antarctica, including Pseudomonas antarctica, P. meridiana, P. proteolytica, P. guinea, P. extremaustralis, $P$. deceptionensis, $P$. prosekii, and $P$. gregormendelii [2]. Nevertheless, these eight species are only a starting point, and it is probable that the diversity of Pseudomonas species in Antarctic is much greater. Indeed, in recent years representatives of new species have been isolated in Antarctica. So, researchers obtained bacterial isolate Pseudomonas sp. 6A1 from marine sediments originating from the Fildes Peninsula Bay, King George Island, Antarctica, that subsequently was identified as P. mandelii [3].

Representatives of the $P$. mandelii species are able to exist and multiply in places where the temperature is constantly low. The optimum growth temperature for $P$. mandelii is $25-30{ }^{\circ} \mathrm{C}$ [4], although this bacterium can grow at $4{ }^{\circ} \mathrm{C}$ but not at $37{ }^{\circ} \mathrm{C}$ [5]. Therefore, P. mandelii is an excellent example of a psychrotolerant bacterium which like psychrophilic bacteria is characterized by a number of structural and functional adaptations that facilitate survival at low temperatures.

To understand the role of these microorganisms in Antarctica, the characterization of its biopolymers is vital. One of these biopolymers is lipopolysaccharide (LPS), the main component of the outer membranes of gram-negative bacteria. Due to the localization of LPS, it is recognized by the host to deploy an immune defence in order to neutralize invading pathogens. However, LPS also promotes bacterial survival in a host environment by protecting the bacteria from these threats. It's known [6] that composition and structure of LPS are diagnostically significant.
This determines the aim of the work - to isolate lipopolysaccharides from Antarctic strain cells, grown at different temperatures, to characterize them chemically, and to study their functional and biological activity.

Materials and methods. The object of the study was isolate U1, originated from moss on Galindez Island in Antarctica. It's identification as Pseudomonas sp. was performed by comparative analysis of pairwise similarity of $16 \mathrm{~S}$ rRNA genes of bacteria with the genes of 16S rRNA of bacteria deposited in the GenBank database using the BLAST software package. On the basis of the data obtained, closely related species were found. According to the analysis, strain was compared with at least 3 of the most closely related strains [7].

Phylogenetic position was determined by constructing dendrograms showing the position of the studied strain among closely related and type species (ClustalX 2.1 and Mega v. 6.00 programs). The tree was built (ClustalX 2.1 program) by the method of neighbours comparison with bootstrap analysis (bootstrap NJ tree) using 1000 bootstrap tests (1000 alternative trees). Then the phylogenetic tree was opened with the Mega v. 6.00 and corrected.

The culture was grown on mesopatamia agar (mattresses) at room temperature for $48 \mathrm{~h}$ and in a refrigerator for $96 \mathrm{~h}$.

LPS was obtained by the classical waterphenolic method [8]. However, in contrast to the water fraction usually used for LPS studies, we also investigated phenolic fraction.

Determination of the chemical composition of LPS was carried out by conventional methods: total carbohydrates - according to Dubois [9], proteins - according to Lowry [10], nucleic acids according to Spirin [11]. The presence of 2-keto-3deoxyoctonic acid (KDO) in LPS was determined by the reaction with thiobarbituric acid [12].

The monosaccharide composition [13] was analyzed as polyol acetates on an Agilent 6890 N/5973 inert chromatography-mass spectrometry system equipped with a DB225mS column $(30 \mathrm{~m} \times 0.25 \mathrm{~mm} \times 0.25 \mu \mathrm{m})$; the carrier gas was helium at a flow rate of $1 \mathrm{~mL} / \mathrm{min}$. The identification of monosaccharides was performed by comparison of the retention times with the authentic samples.

Fatty acid composition was determined by methanolysis of LPS with $1.5 \%$ acetyl chloride in 
methanol $\left(100^{\circ} \mathrm{C}, 4 \mathrm{~h}\right)$. The identification of fatty acids was performed as methyl esters by GLC-MS on Agilent 6890N/5973 inert chromatographymass spectrometry system equipped with an HP $5 \mathrm{~ms}$ column $(30 \mathrm{~m} \times 0.25 \mathrm{~mm} \times 0.25 \mathrm{~nm})$ using the temperature program from 150 to $250{ }^{\circ} \mathrm{C}$ at $4{ }^{\circ} \mathrm{C} / \mathrm{min}$; helium was used as a carrier gas at the flow rate of $1.2 \mathrm{~mL} / \mathrm{min}$. The evaporator temperature was $250{ }^{\circ} \mathrm{C}$ and flow distribution was $1: 100$. For identification of fatty acids, the standard mixture of fatty acid methyl esters and the available databases were used [12].

The quantitative content of individual monosaccharides and fatty acids was expressed as $\%$ to the total sum of peak areas.

Polyacrylamide gel electrophoresis in the presence of sodium dodecyl sulfate (SDS-PAAG electrophoresis) was performed according to Laemmli [14] (4\% concentrating and $12 \%$ separating gel, current $30 \mathrm{~mA}$ ). The load on the gel lane was $20 \mu \mathrm{g}$. To visualize LPS, the gels were stained with silver salts according to Tsai's recommendations [15] as modified by Kulikov [16].

In the study of biological and functional activity, the following LPS concentrations were used: the minimal pyrogenic dose was $7.5 \times 10^{-3} \mu \mathrm{g} / \mathrm{mL}$ per $1 \mathrm{~kg}$ of animal weight (pyrogenicity); $1 \mathrm{mg} / \mathrm{mL}$ (serological studies). The work was conducted in accordance with the "General Ethical Principles of Animal Experiments".

The LPS pyrogenicity was determined in rabbits (breed Chinchilla, age of 1.0-1.5 years) weighing $2.0-3.5 \mathrm{~kg}$. Animals with initial temperature within a range of $0.2{ }^{\circ} \mathrm{C}$ were used. The temperature was measured in $30 \mathrm{~min}$ intervals before the injection and in 1 hour intervals after the injection. The LPS solutions under test were considered apyrogenic if the temperature has not increased more than $1.4{ }^{\circ} \mathrm{C}$ for 3 hours.

For the $\mathrm{O}$-antiserum preparation, heated cells were used ( $2.5 \mathrm{~h}$, boiling water bath); the cell concentration was $2 \times 10^{9} / \mathrm{mL}$. Rabbits were immunized intravenously five times with 4-day intervals (from 0.1 to $1 \mathrm{~mL}$ ). The antigenic activity of LPS was studied by the method of double immunodiffusion in agar according to Ouchterlony [17].

Statistical analysis of the data obtained was carried out using statistical methods, as well as the Excel 2000 computer program.

Results. Earlier authors [7] identified isolate U1 as Pseudomonas sp. by comparing sequences of it's16S rRNA genes with those of microorganisms in the GenBank database. For further identification, we formed an extended list of closely related and type strains of the corresponding species, which were used for phylogenetic analysis (programs ClustalX 2.1, Tree view, Mega v. 6.00). It was shown that the Antarctic bacterial strain U1 associated with green moss has a 99.4 homology percentage with the type strain from the GenBank database NR024902 P. mandelii CIP 105273T. According to these data and proximity to the corresponding cluster of species (Fig. 1), the studied isolate can be identified as $P$. mandelii.

LPS from $P$. mandelii cells, grown at different $\left(+4{ }^{\circ} \mathrm{C}\right.$ and $\left.+20^{\circ} \mathrm{C}\right)$, temperature were isolated by

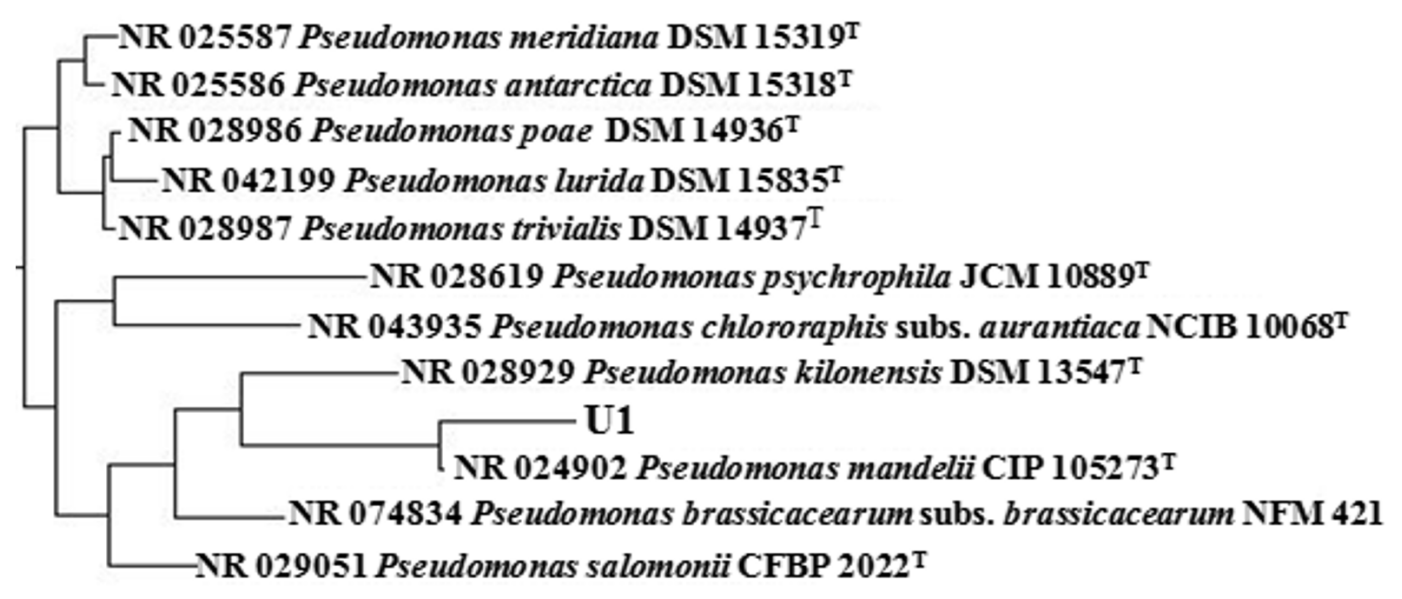

$\stackrel{\stackrel{H}{0.001}}{0.000}$

F i g. 1. Phylogenetic dendrogram based on the analysis of nucleotide sequence of 16S rRNA genes showing the position of strain U1 among closely related Pseudomonas species.

The scale corresponds to 1 substitution per 1000 bp 
the water-phenolic method. During extraction, LPS usually passes into the aqueous phase together with a small amount of proteins and nucleic acids. Since the extraction of LPS from $P$. mandelii U1 with phenol yielded two aqueous fractions, one of which was transparent (LPS 1) and the other was milky color, the latter was subjected to repeated extraction with water (LPS 2). Since it is known that part of the LPS can pass into the phenolic phase due to the presence in it of a hydrophobic hydrocarbon part, the LPS of the phenol fraction (LPS 3) was also studied. Thus, we studied three LPS preparations obtained from cells grown at $20^{\circ} \mathrm{C}$ : $\operatorname{LPS}_{20} 1, \mathrm{LPS}_{20}$ $2, \mathrm{LPS}_{20} 3$. When obtaining LPS from cells grown at $+4{ }^{\circ} \mathrm{C}$, only two fractions were selected: water (LPS 4 1) and phenolic (LPS 3 ).

Taking into account the peculiarities of the used extraction method, proteins and nucleic acids may also be present in LPS. In the case when these impurities are present in large quantities, it becomes necessary to further purify them by ultracentrifugation. As a result of the analysis, it was found that LPS 1 and LPS 1 contained a large amount of nucleic acids (21.7 and 30.3\%, respectively). Therefore, their additional purification by ultracentrifugation was carried out, which led to a significant decrease in the content of nucleic acids to 2.9 and $1.04 \%$, respectively (Table 1).

Comparative analysis indicates that the yield of LPS from both aqueous (LPS 4 1) and phenolic (LPS 3 ) fractions was higher from cells grown at $4{ }^{\circ} \mathrm{C}$ and amounted to 1.95 and $2.6 \%$, respectively. While the yield of LPS isolated from cells grown at $20{ }^{\circ} \mathrm{C}$ was lower and amounted to $\mathrm{LPS}_{20} 1-1.1 \%$, $\mathrm{LPS}_{20} 2-0.9 \%, \mathrm{LPS}_{20} 3-0.5 \%$ (Table 1). However, it was lower than in other Pseudomonas species, the LPS yield in which ( $P$. cepacia) can reach $32 \%$ [18]. The yield of the LPS preparations obtained by us was also lower than in the LPS preparations isolated by us earlier from $P$. chlororapsis subsp. aureofaciens (from 11.3 to $12.9 \%$ ) [19] and P. putida (7.5\%) [20], respectively.

The content of carbohydrates in the aqueous fractions exceeded their content in the phenolic fractions, as expected. However, as in the LPS of other Pseudomonas representatives, the carbohydrate content was not high and ranged from 9.06 to $21.5 \%$ (Table 1 ). The results obtained agree with the data of other authors $[21,22]$ on the content of carbohydrates in LPS preparations of representatives of the species $P$. fruorescens, which is phylogenetically closely related to $P$. mandelii.

The content of KDO, which is a marker molecule of LPS, ranged from 0.04 to $2.5 \%$ (Table 1). One of the possible reasons for the inability to detect $\mathrm{KDO}$ in $\mathrm{LPS}_{4} 1$ may be the shielding of the acid-labile bond between KDO and lipid A due to phosphate groups attached to the polymer under study. Our data on the content of KDO in LPS preparations of the $P$. mandelii $\mathrm{U} 1$ strain are consistent with those obtained from representatives of the phylogenetically closely related species $P$. fruorescens, the KDO content of which ranged from 0.6 to $2.8 \%$, depending on the strain $[21,22]$. The difference in the content of KDO in LPS preparations is also observed in other members of the genus. Thus, in the LPS of $P$. chlororapsis it is $0.5 \%$; P. putida - $0.1 \%$; P. syringae $-1.2-2.3 \%$; $P$. wieringae $-1.3 \%$ [19-21].

Comparative analysis of the monosaccharide composition (Table 2) indicates that all studied LPSs contain mannose (33.5-69.7\%) and rhamnose (3.9-19.0\%). Galactose (14.3-28.7\%) is present in the LPS of phenolic fractions, fucose $(10.5 \%)-$ only in $\mathrm{LPS}_{4} 3$, and glucose $(39.1 \%)$ - in $\mathrm{LPS}_{20} 1$. Heptose (9.7-16.9\%) was found in the LPS of two phenolic fractions and $\mathrm{LPS}_{4} 1$. It was also found unidentified monosaccharide in $\mathrm{LPS}_{20} 2$ (15.4\%), $\mathrm{LPS}_{20} 3$ and $\mathrm{LPS}_{4} 3$ (16.9 and $17.4 \%$, respectively). The data obtained indicate the heterogeneity of the studied LPS on the monosaccharide composition.

Heterogeneity was also found in the composition of fatty acids of the studied LPS, lipid A of which is represented by saturated, as well as 2- and 3-hydroxylated fatty acids with a carbon chain length from $\mathrm{C}_{12}$ to $\mathrm{C}_{18}$ (Table 3 ). The only acid that is present in the composition of lipids A of all LPS

\section{Table 1}

Characteristics of $\boldsymbol{P}$. mandelii LPS

\begin{tabular}{|l|c|c|c|c|c|}
\hline Components & LPS $_{20} 1$ & LPS $_{20} 2$ & LPS $_{20} 3$ & LPS $_{4} 1$ & LPS $_{4} 3$ \\
\hline Yield of LPS to dry cell mass, \% & 1.1 & 0.9 & 0.5 & 1.95 & 2.6 \\
\hline Carbohydrates, \% & 21.5 & 16.9 & 11.8 & 20.07 & 9.06 \\
\hline Protein, \% & 2.46 & 9.5 & 16.2 & 1.4 & 3.0 \\
\hline Nucleic acids, \% & 2.9 & 2.2 & 0.9 & 0.05 & 1.04 \\
\hline KDO, \% & $\sim 0.04$ & 2.5 & 1.75 & - & 0.55 \\
\hline
\end{tabular}


is $\mathrm{C}_{12: 0}(10.18-65.15 \%)$. Only $\mathrm{LPS}_{4} 3$ contains $3-\mathrm{OH}-\mathrm{C}_{10: 0}(8.09 \%)$. 2-OH-C ${ }_{12: 0}$ is present in $\mathrm{LPS}_{20}$ $1, \mathrm{LPS}_{20} 3$ and $\mathrm{LPS}_{4} 3$ (30.71, 5.23 and $7.72 \%$, respectively). $3-\mathrm{OH}-\mathrm{C}_{12: 0}$ was found in three studied LPS: $\operatorname{LPS}_{20} 2$ (7.42 \%), LPS 3 $3(13.09 \%)$, and LPS $_{4} 3(11.37 \%)$. Hexadecanoic $\left(\mathrm{C}_{16: 0}\right)$ is absent only in $\mathrm{LPS}_{20} 1$. Unidentified (X) fatty acid, as well as 9- and 10-octadecanoic acids, are found only in $\mathrm{LPS}_{4}$ 3. Iso-hexadecanoic (i-C $\left.\mathrm{C}_{16: 0}\right)$ acid is present only in $\mathrm{LPS}_{20} 2$ and $\mathrm{LPS}_{4} 3$ (6.82 and $8.47 \%$, respectively). Iso-heptadecanoic $\left(\mathrm{i}-\mathrm{C}_{17: 0}\right)$ was not detected only in $\mathrm{LPS}_{4} 3$. In the rest of the studied LPS, it was present from 10.46 to $59.11 \%$. LPS 3 contains octadecanoic $\mathrm{C}_{18: 0}$ acid.

The results of SDS-PAAG electrophoresis (Fig. 2) indicate that P. mandelii LPS is a heterogeneous population of molecules with varying degrees of electrophoretic mobility. Molecules that pass a greater distance during electrophoretic distribution correspond to an unsubstituted core oligosaccharide, while slowly moving ones represent a core oligosaccharide that is replaced by $\mathrm{O}$-specific polysaccharide chains. The heterogeneity of the slowly moving components can be explained by the different lengths of the $\mathrm{O}$-specific polysaccharide chain: the mobility decreases with the addition of one repeating unit.

Comparative analysis of electrophoretograms indicates the presence of differences in the distribution of electrophoretic lines of the studied LPS. Thus, $\mathrm{LPS}_{20} 2$ and $\mathrm{LPS}_{4} 1$ are characterized by the presence of weakly moving lines, indicating the presence of high molecular weight $\mathrm{O}$-specific polysaccharide chains, which are lagging behind in the composition of other studied LPS. Moreover, LPS $_{4} 1$ contains a greater number of these lines. $\mathrm{LPS}_{20} 1, \mathrm{LPS}_{20} 2$ and $\mathrm{LPS}_{4} 1$ are also characterized by the presence of medium-moving lines, but their number was different and the LPS can be arranged in the following ascending order: $\operatorname{LPS}_{20} 1, \mathrm{LPS}_{20} 2$,

\section{Table 2}

Monosaccharide composition of $P$. mandelii LPS

\begin{tabular}{|l|c|c|c|c|c|}
\hline \multirow{2}{*}{ Monosaccharides } & \multicolumn{5}{|c|}{ Preparations } \\
\cline { 2 - 6 } & LPS $_{20} 1$ & LPS $_{20} 2$ & LPS $_{20} 3$ & LPS $_{4} 1$ & LPs $_{4} 3$ \\
\cline { 2 - 6 } & \multicolumn{5}{|c|}{$\%$ to the total sum of peak areas } \\
\hline Rhamnose & $9.9 \pm 0.45$ & $3.9 \pm 0.2$ & $19.0 \pm 0.95$ & $6.3 \pm 0.39$ & $16.8 \pm 0.83$ \\
\hline Fucose & - & - & - & - & $10.5 \pm 0.52$ \\
\hline X-1 & - & $15.4 \pm 0.77$ & $16.9 \pm 0.84$ & - & $17.4 \pm 0.87$ \\
\hline Mannose & $33.5 \pm 1.57$ & $46.7 \pm 2.33$ & $41.2 \pm 2.15$ & $69.7 \pm 3.48$ & $34.4 \pm 1.17$ \\
\hline Galactose & $17.5 \pm 0.81$ & $28.7 \pm 1.43$ & - & $14.3 \pm 0.71$ & - \\
\hline Glucose & $39.1 \pm 1.95$ & - & - & - & - \\
\hline Heptose & - & - & $16.9 \pm 0.84$ & $9.7 \pm 0.49$ & $14.4 \pm 0.72$ \\
\hline
\end{tabular}

Legend: “-” monosaccharide not detected.

\section{Table 3}

Fatty acid composition of $P$. mandelii U1 LPS

\begin{tabular}{|c|c|c|c|c|c|}
\hline \multirow{2}{*}{ Fatty acid } & $\mathrm{LPS}_{20} 1$ & $\mathrm{LPS}_{20} 2$ & $\mathrm{LPS}_{20} 3$ & $\mathrm{LPS}_{4} 1$ & $\mathrm{LPS}_{4} 3$ \\
\hline & \multicolumn{5}{|c|}{$\%$ to the total sum of peak areas } \\
\hline 3-hydroxydecanoic 3-OH-C $\mathrm{C}_{10: 0}$ & - & - & - & - & $8.09 \pm 0.39$ \\
\hline dodecanoic $\mathrm{C}_{12: 0}$ & $10.18 \pm 0.51$ & $51.66 \pm 2.58$ & $65.15 \pm 3.25$ & $11.68 \pm 0.51$ & $30.95 \pm 1.57$ \\
\hline 2-hydroxydodecanoic 2-OH-C & $30.71 \pm 1.56$ & - & $5.23 \pm 0.26$ & - & $7.72 \pm 0.37$ \\
\hline 3-hydroxydodecanoic 3-OH-C $\mathrm{C}_{12: 0}$ & - & $7.42 \pm 0.37$ & $13.09 \pm 0.66$ & - & $11.37 \pm 0.49$ \\
\hline Iso-hexadecanoic $\mathrm{iC}_{16: 0}$ & - & $6.82 \pm 0.34$ & - & - & $8.47 \pm 0.41$ \\
\hline Hexadecanoic $\mathrm{C}_{16: 0}$ & - & $12.04 \pm 0.61$ & $6.07 \pm 0.31$ & $19.71 \pm 0.91$ & $11.4 \pm 0.5$ \\
\hline Iso-heptadecanoic $\mathrm{iC}_{17: 0}$ & $59.11 \pm 3.01$ & $22.06 \pm 1.11$ & $10.46 \pm 0.52$ & $29.93 \pm 1.16$ & - \\
\hline $\mathrm{X}$ & - & - & - & $38.68 \pm 1.59$ & $7.17 \pm 0.38$ \\
\hline 9-octadecanoic $\mathrm{C}_{18: 0}$ & - & - & - & - & $11.84 \pm 0.51$ \\
\hline 10-octadecanoic $\mathrm{C}_{18: 0}$ & - & - & - & - & $2.99 \pm 0.03$ \\
\hline
\end{tabular}

Legend: "-" fatty acid not detected. 
$\mathrm{LPS}_{4} 1$. As for the LPS of phenolic fractions, the pattern of electrophoregrams is similar; however, in contrast to the LPS of the aqueous fractions, R-LPS predominated in them.

Thus, electrophoresis confirmed the heterogeneity of $P$. mandelii LPS, represented by S-,

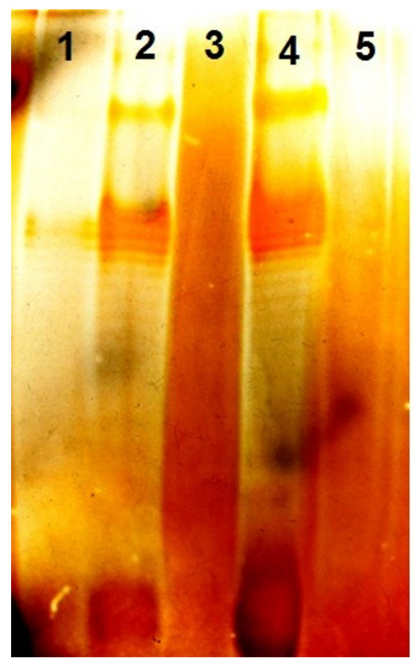

$$
\begin{aligned}
& 1-\operatorname{LPS}_{20} 1 \\
& 2-\operatorname{LPS}_{20} 2 \\
& 3-\operatorname{LPS}_{20} 3 \\
& 4-\operatorname{LPS}_{4} 1 \\
& 5-\operatorname{LPS}_{4} 3
\end{aligned}
$$

\section{F i g. 2. Electrophoretic distribution in the SDS-PAAG system of P. mandelii LPS}

SR- and R-forms.

The study of pyrogenicity (Fig. 3) showed that already after the first thermometry, which was carried out one hour after the introduction of the minimum pyrogenic dose of LPS 201 and LPS $_{20} 3$ preparations to experimental rabbits, a decrease in their body temperature by 0.6 and $0.4{ }^{\circ} \mathrm{C}$ respectively was observed (Fig. 3). On the second hour of the experiment, the body temperature of the rabbits increased by $0.4{ }^{\circ} \mathrm{C}$ and remained unchanged during the third hour after the introduction of $\mathrm{LPS}_{20} 1$ and $\mathrm{LPS}_{20} 3$. At the same time, with the introduction of the minimal pyrogenic dose of the $\mathrm{LPS}_{20} 2$ preparation, an increase in body temperature from $0.2{ }^{\circ} \mathrm{C}$ to $0.7^{\circ} \mathrm{C}$ was observed during the first two hours after the

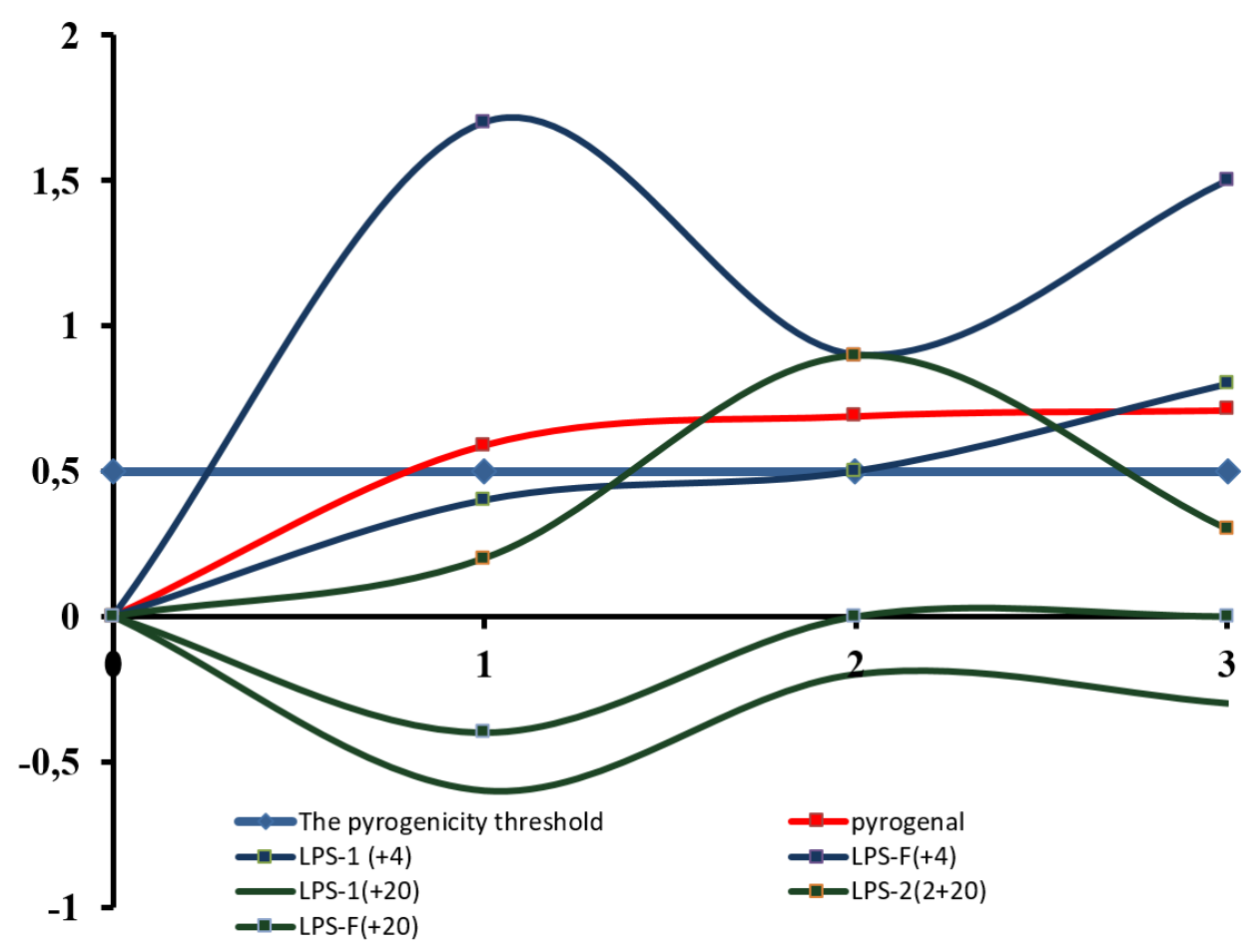

$F$ i g. 3. Pyrogenic activity of LPS preparations of $P$. mandelii $\mathrm{U} 1$ after administration to experimental animals 
introduction of the minimum pyrogenic dose, and starting from the third hour of measurement, the temperature decreased by $0.5{ }^{\circ} \mathrm{C}$. Thus, we have shown that the $\mathrm{LPS}_{20} 1$ and LPS 203 preparations are apyrogenic. In comparison with them, the $\mathrm{LPS}_{4} 3$ preparation exhibited high pyrogenic activity not only in comparison with the above-mentioned preparations, but also the pharmaceutical preparation pyrogenal, the active ingredient of which is Shigella typhi LPS. The LPS of the $P$. putida strain exhibited a similar apyrogenicity. So, after its administration to laboratory animals, a decrease in body temperature was also observed, which indicated a nonpyrogenic effect in comparison with pyrogenal. At the same time, the introduction of a minimal pyrogenic dose of P. chlororapsis LPS [19] to experimental animals led to an increase in their body temperature. These results coincide with the data obtained in the study of the LPS 3 . Thus, the study of the pyrogenic activity of the $P$. mandelii U1 LPS preparations showed that the temperature of bacterial growth does not affect the pyrogenic activity.

The study of the immunochemical properties of LPS was carried out using polyclonal O-antisera as antibodies and LPS as antigens indicated that in homologous systems LPS exhibited serological activity. LPS obtained from $P$. mandelii U1 cells, grown at $20{ }^{\circ} \mathrm{C}$, had a complex antigenic composition and gave two clear lines of precipitation at a concentration of $1 \mathrm{mg} / \mathrm{mL}$. LPS obtained from $P$. mandelii $\mathrm{U} 1$ cells, grown at $4{ }^{\circ} \mathrm{C}$, gave one line, which indicates their serological

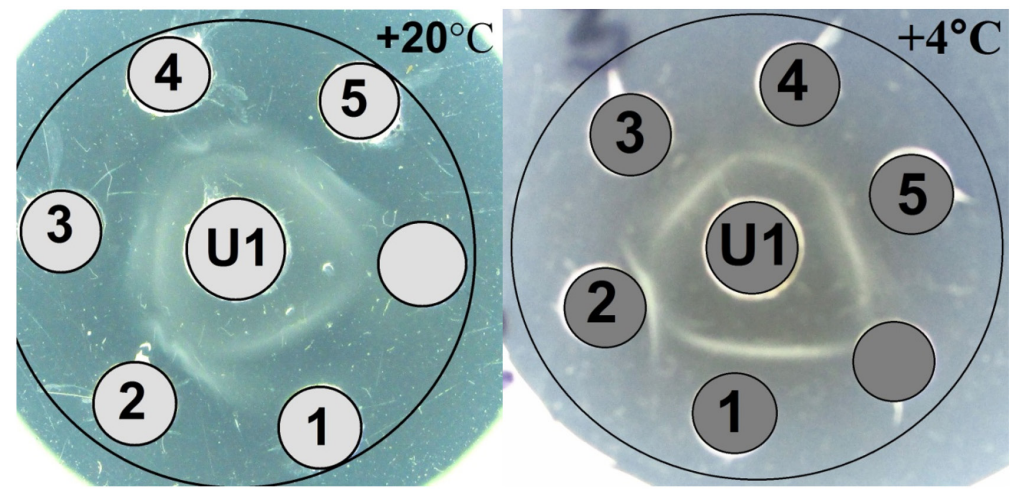

F i g. 3. Double immunodiffusion reaction in Ouchterloni agar of $\mathrm{O}$-antisera to $P$. mandelii $\mathrm{U} 1$ cells grown at $+4{ }^{\circ} \mathrm{C}$ and $+20{ }^{\circ} \mathrm{C}$ (central wells): $1-\operatorname{LPS}_{20} 1,2-\operatorname{LPS}_{20} 2,3-\mathrm{LPS}_{20} 3,4-\mathrm{LPS}_{4} 1$, $5-\operatorname{LPS}_{4} 3$

homogeneity.

Discussion. For the first time $P$. mandelii was isolated from mineral waters in France [23] and Korea [24], soils in China [25], river sediments from the Aldan River in the Central Yakutia region of Siberia [26], and in potato crop waters in New Brunswick, Canada [27].

However, the interest of researchers in $P$. mandelii increased after the discovery of representatives of the species in Antarctica. These bacteria produce a large amount of secondary metabolites, some of which are essential for their survival. One of these metabolites is alginate, extracellular polysaccharide of all pseudomonads. Alginates are one of the polymers with the highest industrial projection, since its applications are so varied that it is used in products for biomedicine, in the food, and cosmetics industries. At present the bacterium most used to produce alginate and whose quality is fully tested is Azotobacter vinelandii. To know in depth, the causes of the genetic overproduction in this Antarctic strain of this polymer and to evaluate its quality are the main challenges at the biotechnological level. In addition to this, the psychrotolerant nature of this new strain of $P$. mandelii makes it possible to explore new strategies for the industrial production of this material $[28,29]$. Therefore, the study of the properties of new representatives of P. mandelii is of both fundamental and practical interest for researchers.

The object of our research P. mandelii U1, isolated from moss at a temperature of $5{ }^{\circ} \mathrm{C}$, also refers to psychrotolerant microorganisms. A characteristic feature of LPS isolated from P. mandelii cells, grown at different temperatures $\left(20{ }^{\circ} \mathrm{C}\right.$ and $\left.4{ }^{\circ} \mathrm{C}\right)$ is their heterogeneity. This is evidenced by the data of the monosaccharide composition, electrophoretic distribution, which showed that $P$. mandelii produces $\mathrm{S}$ - and SR-forms 
of LPS, differed in the length of the O-specific polysaccharide chains, which is determined by both morphological and genetic characteristics of the strain. The R-form of LPS is also present, which does not contain an $\mathrm{O}$-specific polysaccharide chains.

Structural heterogeneity is also inherent in LPS lipid A. This is evidenced by the data of the fatty acid composition. In LPS grown at $4{ }^{\circ} \mathrm{C}$ no unsaturated fatty acids were found, while such ones are synthesized in LPS of other bacteria grown in the cold, in response to a decrease in growth temperature [30]. It is likely that the functions of unsaturated fatty acids that prevent the tight packing of hydrocarbon chains in this case can be fulfilled, for example, by 3-acyloxyalkanoic acids, which are present in large amounts in the LPS of other bacteria, for example, Yersinia pestis, grown in the cold.

The process of LPS synthesis and the relative content of various types of LPS molecules in cells are regulated by the temperature of microorganisms growing. Usually, cold variants of bacteria produce LPS with shorter chains than LPS from cells grown at a higher temperature. At the same time, we found that $P$. mandelii LPS obtained from cells grown at $4{ }^{\circ} \mathrm{C}$ has a longer LPS chain. It can be assumed that such an atypical change in the LPS composition with a change in the growth temperature may be due to the belonging of $P$. mandelii to a psychrotrophic microorganism capable of growing and multiplying at low temperatures, in particular, $4{ }^{\circ} \mathrm{C}$, and indicating the existence of unusual thermal adaptation mechanisms in this microorganism.

Interesting results were obtained when studying the immunochemical properties of the tested LPS. Regardless of the temperature at which P. mandelii cells were grown, LPS derived from them exhibited antigenic activity in a homologous system. However, if all the studied LPS, when interacting with antiserum obtained for $P$. mandelii cells, grown at $20{ }^{\circ} \mathrm{C}$, were characterized by a complex antigenic composition: they gave two lines of precipitation (except for $\mathrm{LPS}_{20} 1$, which gave one line of precipitation), then when interacting with antisera, obtained to cells that were grown at $4{ }^{\circ} \mathrm{C}$, LPS gave only one precipitation line. Probably, only one type of antibodies is present in such an antiserum.

The researchers also noted changes in the composition and properties of LPS caused by changes in the temperature of cultivation for psychrotrophic bacteria, which suggests the existence of common adaptation mechanisms in them, different from those characteristic of mesophilic bacteria.

Conclusions. For the first time lipopolysaccharides were isolated from Pseudomonas mandelii U1 cells, grown at $4{ }^{\circ} \mathrm{C}$ and $20^{\circ} \mathrm{C}$. A characteristic feature of these LPS is their heterogeneity. This is evidenced by the data of the monosaccharide and fatty acid composition, electrophoretic distribution, which showed that $P$. mandelii produces S- and SRforms of LPS, differed in the length of the O-specific polysaccharide chains. LPS, obtained from cells, grown at different temperatures, are differed by serological activity.

Acknowledgments. The authors are grateful to the team of the Center for Collective Use of the National Academy of Sciences of Ukraine for their help in conducting gas chromatography-mass spectrometric studies.

\section{ЛІПОПОЛІСАХАРИД PSEUDOMONAS MANDELII, ІЗОЛЬОВАНИЙ В АНТАРКТИЦІ}

\author{
О.С. Броварська, Л.Д. Варбанець, \\ Г.В. Гладка, А.Д. Герман, О.Б. Таширев
}

Інститут мікробіології і вірусології ім. Д.К.Заболотного НАН України, вул. Академіка Заболотного, 154, Київ, 03143, Украӥна

$\mathrm{P}$ е 3 ю м е

Представники виду Pseudomonas mandelii здатні існувати і розмножуватися в місцях, де температура постійно низька. Оптимальна температура росту для $P$. mandelii становить $25-30{ }^{\circ} \mathrm{C}$, хоча ця бактерія може рости при $4{ }^{\circ} \mathrm{C}$, але не при $37^{\circ} \mathrm{C}$. Тому P. mandelii є прекрасним прикладом психротолерантної бактерії, яка, як і психрофільні бактерії, характеризується рядом структурних та функціональних пристосувань, що сприяють виживанню при низьких температурах. Для розуміння ролі цих мікроорганізмів в Антарктиці життєво важливим $\epsilon$ характеристика його біополімерів. Одними з таких біополімерів є ліпополісахариди (ЛПС), склад і структура яких є діагностично значущими. Це визначає мету роботи - виділити ліпополісахариди 3 клітин антарктичного штаму P. mandelii, вирощеного за різних температур, охарактеризувати хімічно та вивчити їх функціональ- 
ну та біологічну активності. Методи. Об'єктом дослідження був Pseudomonas sp. U1, ізольований 3 моху на острові Галиндес в Антарктиці. ЛПС екстрагували 3 висушених клітин 45 \%-ним розчином фенолу у воді при 65-68 ${ }^{\circ} \mathrm{C}$ методом Вестфала та Янна. Кількість вуглеводів визначали фенольно-сірчаним методом. Вміст вуглеводів визначали відповідно до калібрувальної кривої, яку будували з використанням глюкози як стандарту. Вміст нуклеїнових кислот визначався методом Спірина, білка - Лоурі. Серологічну активність ЛПС досліджували подвійною імунодифузією в агарі методом Оухтерлоні. Електрофорез у поліакриламідному гелі в присутності додецилсульфату натрію (електрофорез SDS-PAAG) проводили за Леммлі. Результати. В результаті філогенетичного аналізу (програми ClustalX 2.1, Tree view, Mega v. 6.00) було показано, що антарктичний штам бактерій U1 Pseudomonas sp., асоційований із зеленим мохом, має 99,4 \% гомології з типовим штамом з бази даних GenBank NR024902 P. mandelii CIP 105273Т. Відповідно до цих даних та близькості до відповідного кластеру видів досліджуваний ізолят можна ідентифікувати як P. mandelii. Характерною особливістю ЛПС, виділених з клітин P. mandelii, вирощених при різних температурах $\left(20^{\circ} \mathrm{C}\right.$ i $\left.4{ }^{\circ} \mathrm{C}\right)$, є їх гетерогенність. Про це свідчать дані складу моносахаридів, електрофоретичного розподілу, які показали, що P. mandelii продукує S- та SR-форми LPS, які відрізняються довжиною О-специфічних полісахаридних ланцюгів. Також присутня R-форма ЛПС, яка не містить

1. Kriss AE, Mitskevich IN, Rozanova EP, Osnitskaia LK. [Microbiological studies of the Wanda Lake (Antarctica)]. Mikrobiologiia. 1976; 45(6):1075-1081. Russian.

2. FelipeVásquez-Ponce, Sebastián HigueraLlantén, María S. Pavlov, Sergio H. Marshall, Jorge Olivares-Pacheco. Phylogenetic MLSA and phenotypic analysis identification of three probable novel Pseudomonas species isolated on King George Island, South Shetland, Antarctica. Brazilian journal of microbiology. 2018; 49(4):695702. https://doi.org/10.1016/j.bjm.2018.02.005.

3. Sebastián Higuera-Llantén, Felipe VásquezPonce, Matías Núñez-Gallegos, María Soledad Pavlov, Sergio Marshall, Jorge Olivares-Pacheco. Phenotypic and genotypic characterization
О-специфічних полісахаридних ланцюгів. Структурна гетерогенність властива також ліпіду А ЛПС. Про це свідчать дані складу жирних кислот. У ЛПС, вирощених при $4{ }^{\circ} \mathrm{C}$, не виявлено ненасичених жирних кислот. В той же час такі жирні кислоти синтезуються в ЛПС інших бактерій, вирощених на холоді у відповідь на зниження температури зростання. Дослідження імунохімічних властивостей ЛПС з використанням поліклональних О-антисироваток як антитіл та ЛПС як антигенів свідчать про те, що в гомологічних системах ЛПС проявляв серологічну активність. ЛПС, отриманий з клітин $P$. mandelii $\mathrm{U} 1$, вирощених при $20{ }^{\circ} \mathrm{C}$, мав складний антигенний склад і давав дві чіткі лінії преципітації в концентрації 1 мг/мл. ЛПС, отримані з клітин P. mandelii $\mathrm{U} 1$, вирощених при $4{ }^{\circ} \mathrm{C}$, давали тільки одну лінію преципітації, що вказує на їх серологічну однорідність. Висновки. Вперше з клітин P. mandelii U1, вирощених при $4{ }^{\circ} \mathrm{C}$ і $20{ }^{\circ} \mathrm{C}$, були виділені ЛПС. Характерною особливістю ЛПС є їх гетерогенність. Про це свідчать дані складу моносахаридів, жирних кислот, електрофоретичного розподілу, які показали, що P. mandelii продукує S- та SR-форми LPS, що відрізняються довжиною О-специфічних полісахаридних ланцюгів. ЛПС, одержані з клітин, які культивували за різних температур, відрізняються серологічною активністю.

Ключові слова: антарктичний штам U1 Pseudomonas mandelii, ліпополісахарид, моносахаридний та жирнокислотний склад, пірогенність, серологічна активність.

of a novel multi-antibiotic-resistant, alginate hyperproducing strain of Pseudomonas mandelii isolated in Antarctica. Polar Biology. 2018; 41:469-480.

4. Hong S, Lee C, Jang S-H. Purification and properties of an extracellular esterase from a cold-adapted Pseudomonas mandelii. Biotechnol Lett 2012; 34:1051-5. https://doi.org/10.1007/ s10529-012-0866-y

5. Gratia E, Weekers F, Margesin R, D'Amico S, Thonart P, Feller G. Selection of a coldadapted bacterium for bioremediation of wastewater at low temperatures. Extremophiles 2009; 13:7638. https://doi.org/10.1007/s00792-009-0264-0

6. Zdorovenko GM, Varbanets LD, Zdorovenko EL, Posur VK. Lipopolysaccharides: organi- 
zation of macromolecules, composition, structure, functional, biological activity. In: Structure and biological activity of bacterial biopolymers. VPC Kiev University; 2003. p. 83-156.

7. Vasileva-Tonkova E, Romanovskaya V, Gladka G, Gouliamova D, Tomova I, Stoilova-Disheva $\mathrm{M}$, et al. Ecophysiological properties of cultivable heterotrophic bacteria and yeasts dominating in phytocenoses of Galindez Island, maritime Antarctica. WIBI. 2014; 30(4):1387-1398.

8. Westphal O. Jann K. Bacterial lipopolysaccharides - extraction with phenol. Methods Carbohydr Chem. 1965; 5:83-91.

9. Dubois M, Gilles KA, Hamilton JK, Rebers PA, Smith F. Colorimetric method for determinationn of sugars and related substranses. Anal Chem. 1956; 28(3):350-356.

10. Lowry OH, Rosenbrough NJ, Farr LA., Randal RJ. Protein measurement with the Folin reagent. J Biol Chem. 1951; 193(5):265-275.

11. Spirin AS. [Spectrophotometric determination of total nucleic acids]. Biochemistry. 1958; 23(5):656-662. Russian.

12. Varbanets LD, Zdorovenko GM, Knirel YuA [Methods of endotoxin investigations]. K: Naukova Dumka, 2006; 237. Russian.

13. Albershein P, Nevis DJ, English PD, Karr A. A method for analysis of sugars in plant cell wall polysaccharides by gasliquid chromatography. Carbohyd Res. 1967; 5(3):340-345.

14. Laemmli UK. Cleavage of proteins during the assembly of the head of bacteriophage T4. Nature. 1970; 227:680-685.

15. Tsai CM, Frash CE. A sensitive silver stain for detecting lipopolysaccharides in polyacrilamide gels. Anal Biochem. 1982; 119:115-119.

16. Kulikov EE, Golomidova AK, Prokhorov NS, Ivanov PA, Letarov AV. High-throughput LPS profiling as a tool for revealing of bacteriophage infection strategies. Sci Rep. 2019; 9(1):2958. https://doi: 10.1038/s41598-019-39590-8

17. Ouchterlony O. Diffusion in gel methods for immunological analysis. Progr Allergy. 1962; $6: 3-15$.

18. Kasyanchuk NV. [Chemical composition of lipopolysaccharides of cell membranes of the Pseudomonas genus bacteria]. Mikrobiol Z. 1979;
41(1):6-11. Russian.

19. Varbanets LD, Zdorovenko EL, Kiprianova EA, Avdeeva LV, Brovarska OS, Rybalko SL. Characterization of Pseudomonas chlororapsis lipopolysaccharides. Microbiology (Moscow). 2015; 84(6):680-90. https://doi.org/10.7868/ S0026365615060142

20. Brovarska OS, Varbanets LD, Likhanov AF. [Characteristic of Pseudomonas putida lipopolysaccharide]. Mikrobiol Z. 2020; 82(1):33-42. Ukrainian. https://doi.org/10.15407/microbiolj82.01.033

21. Veremeichenko SN, Zdorovenko GM. [Specific structural features and immunomodulatory properties of the lipopolysaccharides of Pseudomonas bacteria]. Appl Biochem Microbiol. 2008; 44(6):571-579. Russian.

22. Veremeichenko SN, Vodyanik M, Zdorovenko GM. [Structural characteristics and biological properties of Pseudomonas fluorescens lipopolysaccharides]. Appl Biochem Microbiol. 2005; 41(4):365-371. Russian.

23. Verhille S, Baida N, Dabboussi F, Izard D, Leclerc H. Taxonomic study of bacteria isolated from natural mineral waters: Proposal of Pseudomonas jessenii sp. nov. and Pseudomonas mandelii sp. Syst Appl Microbiol. 1999; 22:45-58. https:// doi.org/10.1016/S0723-2020(99)80027-7.

24. Jang S-H, Kim J, Kim J, Hong S, Lee C. Genome sequence of cold-adapted Pseudomonas mandelii Strain JR-1. J Bacteriol. 2012; 194:3263. https:// doi.org/10.1128/JB.00517-12

25. Weon H-Y, Dungan RS, Kwon S-W, Kim J-S The phylogeny of fluorescent pseudomonads in an unflooded rice paddy soil. Ann Microbiol. 2007; 57:299-306. https://doi.org/10.1007/ BF03175064

26. Kondakova AN, Drutskaya MS, Shashkov AS, Nedospasov SA, Akimov VN, Arbatsky NP, et al. Structure of the O-polysaccharide of Pseudomonas mandelii CYar1 containing 3,6-dideoxy-4-C[(S)-1-hydroxyethyl]-d-xylo-hexose (yersiniose A). Carbohydr Res. 2013; 381:138-41.

27. Formusa PA, Hsiang T, Habash MB, Hung Lee, Trevors JT. Genome sequence of Pseudomonas mallei PD30. Genome Announc. 2014; 2(4):1314. doi.10.1128/genome A.00713-14. 
28. Felipe Vásquez-Ponce, Sebastián Higuera-Llantén María, Soledad Pavlov Ramón, RamírezOrellana Sergio H. Marshall, Jorge Olivares-Pacheco. Alginate overproduction and biofilm formation by psychrotolerant Pseudomonas mandelii depend on temperature in Antarctic marine sediments. Electronic Journal of Biotechnology. 2017; 28:27-34. https://doi.org/10.1016/j. ejbt.2017.05.001Get rights and content

29. Higuera-Llantén S, Vásquez-Ponce F, NúñezGallegos M, Pavlov MS, Marshall S, Olivares-
Pacheco J. Phenotypic and genotypic characterization of a novel multi-antibiotic-resistant, alginate hyperproducing strain of Pseudomonas mandelii isolated in Antarctica. Polar Biology. 2017; 41(3):469-80.

30. Wollenweber H-W, Sschlecht S, Luderitz O, Rietschel ET. Fatty acid in lipopolysaccharides of Salmonella species grown at low temperature. Eur J Biochem. 1983; 130:167-171. https://doi.org/10. 1111/j.1432-1033.1983.tb07132.x

Received 20.05.2021 